\title{
THE STABILITY OF AGGREGATES AND ORGANIC CARBON CONTENT AFTER THE APPLICATION OF GYPSUM, SOIL SCARIFICATION AND A SUCCESSION OF AGRICULTURAL CROPS
}

\author{
ESTABILIDADE DE AGREGADOS E TEOR DE CARBONO ORGÂNICO, APÓS \\ APLICAÇÃO DE GESSO, ESCARIFICAÇÃO DO SOLO E SUCESSÃO DE \\ CULTURAS
}

\author{
Eduardo Santos Neves dos SANTOS ${ }^{\mathbf{1}}$; Milton César Costa CAMPOS ${ }^{\mathbf{1}}$; \\ Fernando Gomes de SOUZA ${ }^{2}$; José Maurício CUNHA ${ }^{1}$; Elyenayra Nogueira PINHEIRO ${ }^{1}$; \\ Alan Ferreira Leite de LIMA ${ }^{1}$; Wildson Benedito Mendes BRITO ${ }^{1}$; \\ Paulo Guilherme Salvador WADT ${ }^{3}$ \\ 1. Universidade Federal do Amazonas - UFAM, Humaitá, AM, Brasil. mcesarsolos@gmail.com; 2. Universidade Federal de Roraima - \\ UFRR, Boa Vista, RR, Brasil; 3. Embrapa Agroflorestal, Porto Velho, RO, Brasil.
}

\begin{abstract}
Studies related to the monitoring of soil quality by physical attributes are important for the evaluation and maintenance of the sustainability of agricultural systems, besides indicating the appropriate management of the environment, aiming at its conservation and productivity. The objective of this study was to evaluate the stability of aggregates and organic carbon after the application of gypsum, soil scarification and a succession of crops. The treatments consisted of an absence and addition of gypsum, absence and presence of soil scarification, and three systems of crops in succession. The experimental design was made of randomized blocks, in a $2 \times 2 \times 4$ factorial scheme, with eight replications. The aggregates were evaluated as stabled in water and soil organic carbon content. The treatment where gypsum was applied, as well as the soybean/maize/brachiaria/fallow (SMBF) succession system, presented better results in soil aggregation and higher levels of organic carbon.
\end{abstract}

KEYWORDS: Soil management. Physical attributes. Soil degradation.

\section{INTRODUCTION}

Agricultural practices, when performed improperly, result in changes of both physical and chemical soil attributes, such as aggregation, which is one of the most important factors for the conservation and maintenance of the environmental functions of the soil (LOSS et al., 2009; HANKE; DICK, 2017), and organic matter, involved in the processes of cementation and stabilization of aggregates. Moreover, the relationships between soil aggregates and organic matter content are related to mineral fraction, soil fauna, microorganisms, presence of roots, inorganic agents and environmental variables as the main factors involved in the formation and stability of soil aggregates (SALTON et al., 2008).

Aggregate stability is related to several soil physical properties, such as: water retention capacity, infiltration rate, erosion resistance (GARCIA; ROSOLEM，2010; NASCENTE; LI; CRUSCIOL, 2015). The increase of the stability of aggregates provides the best structuring of the soil, supplying it with pore spaces and allowing a better development of a root system for plants, airflow and water in the soil (SALTON et al., 2014).

Root exploration in the soil profile can accelerate the aggregation process of soil particles, by releasing exudates with the interweaving of small clods that, consequently, form larger structures. The cultivation of plants with abundant root systems combined with management practices that add organic matter in soils are essential for the formation and stability of aggregates larger than $2 \mathrm{~mm}$, resulting in the restructuring of soil particles (RIBON et al., 2014).

The organic matter, in its turn, exerts great influence in the processes of formation and stabilization of aggregates. A greater amount of organic matter available to the soil provides a higher structural quality (VEZZANI; MIELNICZUK, 2011; MATAIX-SOLERA et al., 2011). Conservation systems of soil management result in an expressive increase of soil aggregation. The rotation, or crop succession, with frequent residue inputs, associated with other management practices that aim to reduce soil disturbance, typically results in a greater 
The stability...

aggregate stability, which is revealed by higher values of weighted average diameter (WAD) of the aggregates, which, in large part, is related to the effect of management systems on soil organic carbon (BRAIDA et al., 2011).

However, it is still necessary to understand the influence of agricultural inputs and other management practices on aggregation and MOS levels. Among the most commonly used inputs, agricultural gypsum $\left(\mathrm{CaSO}_{4} \cdot 2 \mathrm{H}_{2} \mathrm{O}\right)$ has been used mainly in no-tillage systems to minimize acidity problems. This happens because gypsum is an excellent source of $\mathrm{Ca}(20 \%)$ and S (15-18\%). The increase of these nutrients may favor deep root growth and promote the carryover of other bases, such as $\mathrm{Mg}^{2+}$ and $\mathrm{K}^{+}$to deeper soil layers (FOIS et al., 2018). In addition, when applied to the soil, gypsum reacts with $\mathrm{Al}^{3+}$ and forms complex ionic pairs, making it less toxic $\left(\mathrm{AlSO}^{4+}\right)$ to the plants and providing exchangeable bases $\left(\mathrm{Ca}^{2+}\right.$ and $\left.\mathrm{S}\right)$ in the subsoil, due to its movement, that is about 150 times higher than limestone (ZAMBROSI; ALLEONI; CAIRES, 2007; MASCHIETTO, 2009; NEIS et al., 2010). Thus, gypsum is considered a soil conditioner with little effect on $\mathrm{pH}$, compensating for the surface effect of limestone, since it even acts underground, without the need for incorporation, increasing the volume of soil to be explored and the tolerance of plants to drought in the soil (ARF eet al., 2014; ZANDONÁ et al., 2015).

Another practice that has been employed, and indicated for soils suspected of compaction, is soil scarification, which generates immediate benefits with the rupture of thickened layers, such as density reduction, increased surface roughness,
SANTOS, E. S. N. et al.

hydraulic conductivity and water infiltration rate in the soil (MAZURANA et al., 2011). According to Tormena, Fidalski and Rossi Junior (2008), the adoption of a planned crop rotation system is essential for the maintenance of structural soil quality in no-tillage systems. Nevertheless, little is known about the benefits of using crops succession and input MOS in the soil aggregation, besides the influences caused by the use of gypsum and scarification in the soil.

Studies on soil quality monitoring by physical attributes are important for assessing and maintaining the sustainability of agricultural systems, as well as indicating the appropriate management of the environment, aiming at its conservation and productivity (MOTA; FREIRE; ASSIS JÚNIOR, 2013). Therefore, the objective of this study was to evaluate the stability of aggregates and organic carbon content, after the application of gypsum, soil scarification and a succession of crops.

\section{MATERIAL AND METHODS}

The experimental area was located at the Embrapa Rondônia headquarter, in the city of Porto Velho, capital of the state of Rondônia (RO), $\left(08^{\circ}\right.$ 47 ' 42 ''S, $63^{\circ} \quad 50^{\prime} \quad 45^{\prime}$ ' $\left.\mathrm{W}\right)$, elevation of approximately 95 meters (Figure 1). The average annual rainfall is $2,200 \mathrm{~mm}$, with a dry season from June to September; the average annual temperature is $24.9{ }^{\circ} \mathrm{C}$ and the average relative humidity is $89 \%$. The climate of the region is defined as humid tropical, according to the Köppen classification. The soil of the experimental area was classified as a dystrophic Red-Yellow Latosol (EMBRAPA, 2013).

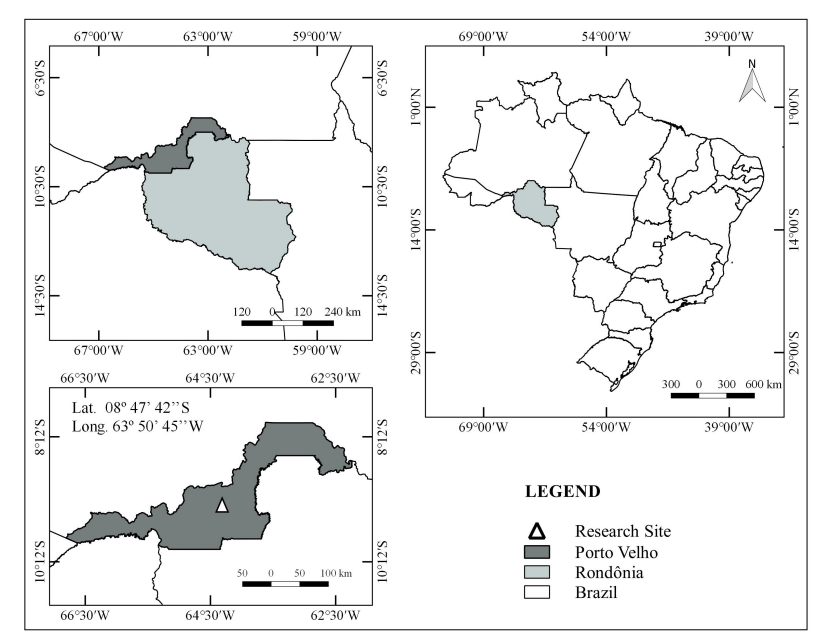

Figure 1. Location of the research site in the city of Porto Velho, RO.

Before the implementation of the experiment, the area was cultivated with Brachiaria brizantha cv. Marandú for a period of eighteen years (1990 to 2008); after that, was kept in fallow 
The stability...

SANTOS, E. S. N. et al.

during four years (2009 to 2013). The chemical characterization of the soil, before the

installation of the experiment, is presented in Table 1.

Table 1. Chemical analysis of the soil in the $0.00-0.20 \mathrm{~m}$ layer of the experimental area.

\begin{tabular}{|c|c|c|c|c|c|c|c|c|}
\hline \multirow{2}{*}{$\mathrm{pH} \mathrm{em} \mathrm{H}_{2} \mathrm{O}$} & $\mathrm{Ca}^{2+}+\mathrm{Mg}^{2+}$ & $\mathrm{K}^{+}$ & $\mathrm{Al}^{3+}$ & $\mathrm{H}^{+}+\mathrm{Al}^{3+}$ & $\mathrm{T}$ & SB & OM & $P$ available \\
\hline & \multicolumn{6}{|c|}{$\mathrm{cmolc} \mathrm{dm}^{-3}$} & \multicolumn{2}{|c|}{$\mathrm{mg} \mathrm{dm}^{-3}$} \\
\hline 5.0 & 1.7 & 0.12 & 2.2 & 5.9 & 7.7 & 1.73 & 3.2 & 1.4 \\
\hline
\end{tabular}

$\mathrm{pH}$ : in water; SB: sum of bases; T: CTC at pH 7.0; OM: Organic matter

The experiment began in the year 2013, for the 2014 crop, with a randomized block design, composed of eight blocks, in a $2 \times 2 \times 3$ factorial scheme. The following treatments were used: with and without mechanical soil scarification; absence and presence of agricultural gypsum; and four crop succession systems (soybean/fallow, soybean/maize/fallow, soybean/maize and brachiaria/fallow). Each experimental unit had a 4.5 $\mathrm{m} \times 20 \mathrm{~m}$ dimension, and $27 \mathrm{~m} \times 40 \mathrm{~m}$ for each block, totalizing $160 \mathrm{~m}$ x $54 \mathrm{~m}$, excluding curbstones.

In the implementation of the experiment, the only mechanical practice introduced was soil scarification, with $2,000 \mathrm{~kg} \mathrm{ha}^{-1}$ of gypsum. Both treatments were conducted before soybean planting, in 2013, the first year of the experiment. The seeds available in the Cone Sul [Southern Cone] region of Rondônia were used for planting soybean, maize and brachiaria, according to the following planting density: 260 to 340 thousand plants $\mathrm{ha}^{-1}$ for soybean; 50 to 70 thousand plants $\mathrm{ha}^{-1}$ for maize and $16 \mathrm{~kg} \mathrm{ha}^{-1}$ of brachiaria.

The dates of soybean sowing were in November 2013, December 2014, December 2015 and November 2016; the maize and brachiaria sowing were always done thirty days after the soybean crop. Soybean and maize were cultivated with mechanized sowing and the brachiaria was cultivated by a manual sowing broadcast system.

NPK fertilizers were carried out with the following formulations: $400 \quad \mathrm{~kg}^{-1}$ of $\quad 0-30-15$ formulation in soybean sowing, plus $300 \mathrm{~kg} \mathrm{ha}^{-1}$ of 4-30-10 formulation in maize cultivation (with or without brachiaria) and $150 \mathrm{~kg} \mathrm{ha}{ }^{-1}$ of $25-0-25$ formulation in side-dressing in maize crop (with or without brachiaria), 30 days after maize germination.

To determine the stability of aggregates, samples with preserved structure were collected in the $0.0-0.05,0.05-0.10,0.10-0.20 \mathrm{~m}$ layers. The sample collection was made with a spade, without destructing the clods, which were packed in plastic bags and, later, air-dried. In the preparation of the samples, the clods were hand-cut, taking care not to destroy the aggregates; and then sieved in $9.5 \mathrm{~mm}$ and $4 \mathrm{~mm}$ sieves. The aggregates retained in the smallest sieve were selected for a wet laboratory analysis (EMBRAPA, 2011).

To determine the distribution of aggregate classes, we used the wet sieving, with the machine recommended by Yoder (1936), which was calibrated to run for $15 \mathrm{~min}$ with 32 oscillations per minute. The samples were moistened and transferred to the Yoder apparatus, adapted with 2.0, $1.0,0.5,0.25,0.125,0.063 \mathrm{~mm}$ cut-off mesh sieves (KEMPER; CHEPIL, 1965). After the end of oscillations, the content retained in each of the sieves was kiln-dried at $105^{\circ} \mathrm{C}$, for 24 hours, and then weighed. The class less than $0.060 \mathrm{~mm}$ was calculated by difference, taking into account the initial weight minus the residual moisture and the weight of the other classes as a basis.

The results are expressed as a percentage of the aggregates retained in each of the sieve classes and as the stability of the aggregates evaluated by the Weighted Average Diameter (WAD) obtained by the formula proposed by Castro Filho, Muzilli and Podanoschi (1998), and the Geometric Mean Diameter (GMD), according to Schaller and Stockinger (1953), cited by Alvarenga et al. (1986).

The organic carbon was determined by oxidation of the organic matter via wet with potassium dichromate in a sulfuric medium, using as energy the heat released from the sulfuric acid and/or heating process. The excess of dichromate after oxidation is titrated with a standard solution of Ammonium iron (II) sulfate (Mohr salt) (EMBRAPA, 2011).

The hypothesis of the normality of data was tested by the Shapiro-Wilk test. Data were submitted to analysis of variance, when significant through the $\mathrm{F}$ test, the means were compared by the Scott-Knott test at a 5\% level of probability.

\section{RESULTS AND DISCUSSION}

The higher concentration of organic carbon (OC) was observed in the $0.00-0.05$ and 
$0.05-0.10 \mathrm{~m}$ layers, in the treatments where the application of agricultural gypsum occurred (Table 2). Although no statistical differences were observed in the $0.10 \quad-0.20 \quad \mathrm{~m}$ layer, the gypsum treatment continued to present a higher OC content, probably due to the reaction with exchangeable acidity and base levels increase, which favors the proliferation of soil macrobiota. However, in this layer the most significant treatment was the presence of scarification, presenting the highest OC content $\left(5.4 \mathrm{~g} \mathrm{Kg}^{-1}\right)$. These results may be related to the increase of $\mathrm{Ca}$ along the soil profile, which may have favored the development of the root system in depth, resulting in a greater efficiency of the plant to increase dry matter. The effect of gypsum as a soil conditioner for root growth may play an important role in the increase of organic matter through the deposition of organic residues in depth. It is known that around 27 to $37 \%$ of the soil carbon input originates from the roots (SANTOS et al., 2011). Higher OC levels in the soil, due to the application of gypsum, are a good indication that the use of this technology increases crop yield due to a more efficient use of water and nutrients (ROSSETTO et al., 2013).

The treatment with scarification in the 0.00 -0.05 and $0.05-0.10 \mathrm{~m}$ layers was not significant. However, the $0.10 \quad-0.20 \mathrm{~m}$ layer presented a higher OC content in the soil scarification treatment (Table 2). Scarification results in the preparation with less revolving and, therefore, less incorporation of the straw, remaining, on the surface, a greater cover for soil protection (CARVALHO FILHO et al., 2007).

Table 2. Mean values for in-balance soil carbon levels, due to the effect of agricultural gypsum, soil scarification and crop succession systems, in the $0.00-0.05,0.05-0.10$ and $0.10-0.20 \mathrm{~m}$ layers.

\begin{tabular}{|c|c|c|c|c|}
\hline \multirow{3}{*}{ TREATMENTS } & & \multicolumn{3}{|c|}{ Organic carbon $\left(\right.$ g. $\left.\mathrm{kg}^{-1}\right)$} \\
\hline & & \multicolumn{3}{|c|}{ Layer $(\mathrm{m})$} \\
\hline & & $0.00-0.05$ & $0.05-0.10$ & $0.10-0.20$ \\
\hline \multirow{2}{*}{ Gypsum } & With & $7.8 \mathrm{a}$ & $6.9 \mathrm{a}$ & 5.3 \\
\hline & Without & $7.1 \mathrm{~b}$ & $6.3 \mathrm{~b}$ & 4.8 \\
\hline F TEST & & $*$ & $*$ & ns \\
\hline \multirow{2}{*}{ Scarification } & With & 7.6 & 6.7 & $5.4 \mathrm{a}$ \\
\hline & Without & 7.3 & 6.5 & $4.7 \mathrm{~b}$ \\
\hline F TEST & & ns & ns & $* *$ \\
\hline \multirow{3}{*}{ Succession } & SMBF & $8.2 \mathrm{a}$ & $7.7 \mathrm{a}$ & 4.9 \\
\hline & SMF & $7.6 \mathrm{~b}$ & $6.8 \mathrm{~b}$ & 5.1 \\
\hline & $\mathrm{SF}$ & $7.2 \mathrm{~b}$ & $6.3 \mathrm{~b}$ & 4.2 \\
\hline F TEST & & $*$ & $*$ & ns \\
\hline
\end{tabular}

$\mathrm{SMBF}=$ soybean/maize/brachiaria/fallow; SMF = soybean/maize/fallow; SF = soybean/fallow; ** significant at the $1 \%$ probability level $(\mathrm{p}<.01)$; ${ }^{*}$ significant at the $5 \%$ probability level $(.01=<\mathrm{p}<.05)$; ns not significant $(\mathrm{p}>=.05)$. Means followed by the same lowercase letter in the column do not differ from one another by the Scott-Knott test at the 5\% probability level.

Among crop succession systems, the soybean/maize/brachiaria/fallow (SMBF) system showed the highest amount of $\mathrm{OC}$ in the $0.00-0.05$ and $0.05-0.10 \mathrm{~m}$ layers, the other systems did not differ among themselves (Table 2). Similar results were observed by Oliveira et al. (2010) and by Portela et al. (2010), who verified a significant improvement in the physical attributes of the soil due to the continuous supply of plant material to the soil, mainly through the roots of the crops. The increase of organic matter in the soil acts positively in the recovery process since it proves nutrients from the mineralization and in a better soil structure, in its physical quality, that will interfere in soil porosity and aeration (BONINI; ALVES; MONTANARI, 2015). The products derived from this organic matter are sources of nutrients and specific energy for soil microorganisms that play an important role in aggregation, since the products of microbial decomposition, such as polysaccharides and mucilage, are cementing agents of soil macroaggregates (INAGAKI et al., 2016; SILVA et al., 2016).

Regarding the OC, regardless the evaluated treatments, it can be observed that it decreases when depth increases. This process occurs more strongly in soils under no-tillage, since the residues deposited on the surface are not incorporated into the soil (BRIEDIS et al., 2012).

Evaluating the effect of gypsum, it may be noted that the in the $0.00-0.05 \mathrm{~m}$ layer, gypsum application provided a higher percentage of aggregates, in the class $>2 \mathrm{~mm}$, and larger values of WAD and GMD, indicating that the structure of the soil may have been influenced by the agricultural gypsum in the topsoil surface layer (Table 3 ). 
The stability...

SANTOS, E. S. N. et al.

Table 3. Mean values of the class size of aggregates (GMD, WAD) due of the effect of agricultural gypsum, in the $0.00-0.05,0.05-0.10$ and $0.10-0.20$ m layers.

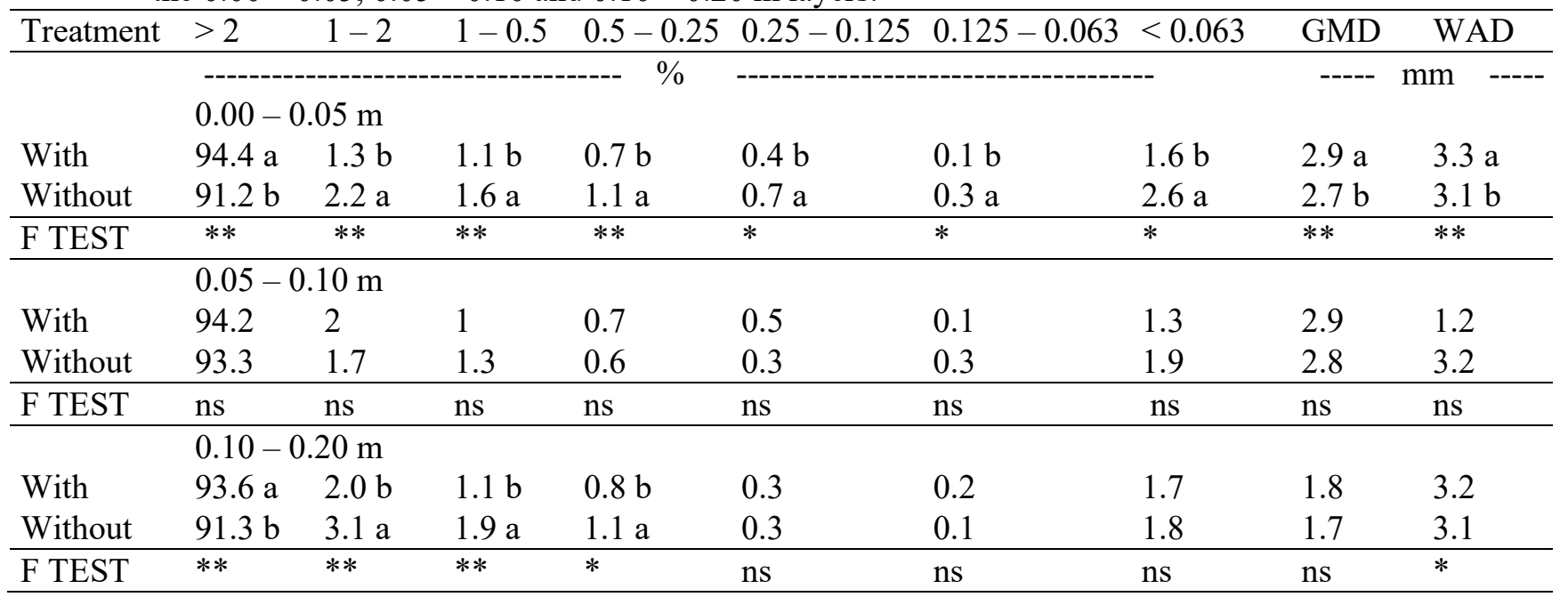

GMD $=$ geometric mean diameter; WAD $=$ weighted average diameter; $* *$ significant at the $1 \%$ probability level $(\mathrm{p}<.01) ; *$ significant at the $5 \%$ probability level $(.01=<\mathrm{p}<.05)$; ns not significant $(\mathrm{p}>=.05)$. Means followed by the same lowercase letter in the column do not differ from one another by the Scott-Knott test at the $5 \%$ probability level.

Gypsum can act indirectly in the formation of aggregates processes, by favoring the development of the root system. The roots act in the formation and stabilization of soil aggregates processes by physical or biochemical processes. In aggregation, both physical and biochemical processes are involved: the first, due to the approximation of mineral particles, caused by the pressure exerted during the growth of these roots; and the latter, due to the release of organic substances in the rhizosphere because of their decomposition, activating microorganisms that exude organic compounds and/or emit hyphae (mycorrhizal fungi), that are temporary cementing agents of soil macroaggregates (COSTA JÚNIOR et al., 2012).

Working with different doses of gypsum, Rosa Junior et al. (2006) concluded that gypsum can act as a conditioner of soil structures, favoring aggregation, and a consequent improvement in soil structure. Stable aggregates in water contribute to improved porosity and, consequently, higher infiltration and resistance to erosion (MATOS et al., 2008). Unstable aggregates, when on the surface, tend to disappear and disperse under the impact of raindrops (ASSIS; BAHIA, 1998).

In the $0.05-0.10 \mathrm{~m}$ layer, no significant differences were observed in the classes of aggregates with the application or no application of gypsum (Table 3). However, in the $0.10-0.20 \mathrm{~m}$ layer, the application of agricultural gypsum presented higher value of aggregates in the class larger than $2 \mathrm{~mm}$. Inversed results were found in the
2-1, 1-0.5 and 0.5- $0.25 \mathrm{~mm}$ classes. The highest WAD value was observed in the application of agricultural gypsum treatment (Table 3). In order to increase aggregate stability, it is necessary to reduce soil nutrient losses (SPIGEL; MENTLER, 2003), while increasing the amount of larger aggregates and total porosity (SHAVER et al., 2002).

In the soil management with or without scarification, in the $0.00-0.05 \mathrm{~m}$ layer, it was possible to observe that in the soil scarification treatment, the class of aggregates smaller than 0.063 $\mathrm{mm}$ presented a higher percentage. In the same layer, it was also observed that a greater concentration of GMD occurs in the treatment where scarification was not performed. In the other layers, no significant differences were observed (Table 4). These results corroborate the tendency presented by the distribution of the aggregate size in water, indicating that scarification of the soil managed under a no-tillage system may have influenced GMD values. The mechanical action of the scarify stems, despite not revolving the soil, promotes the rupture of its structure and intensifies the disintegrating action with the use of the ripper roller, which breaks the clods to reduce the roughness of the ground and facilitate the sowing process (CALONEGO; ROSOLEM, 2008). 
The stability...

SANTOS, E. S. N. et al.

Table 4. Mean values of the class size of aggregates (GMD, WAD) due to the soil scarification effect in the $0.00-0.05,0.05-0.10$ and $0.10-0.20$ m layers.

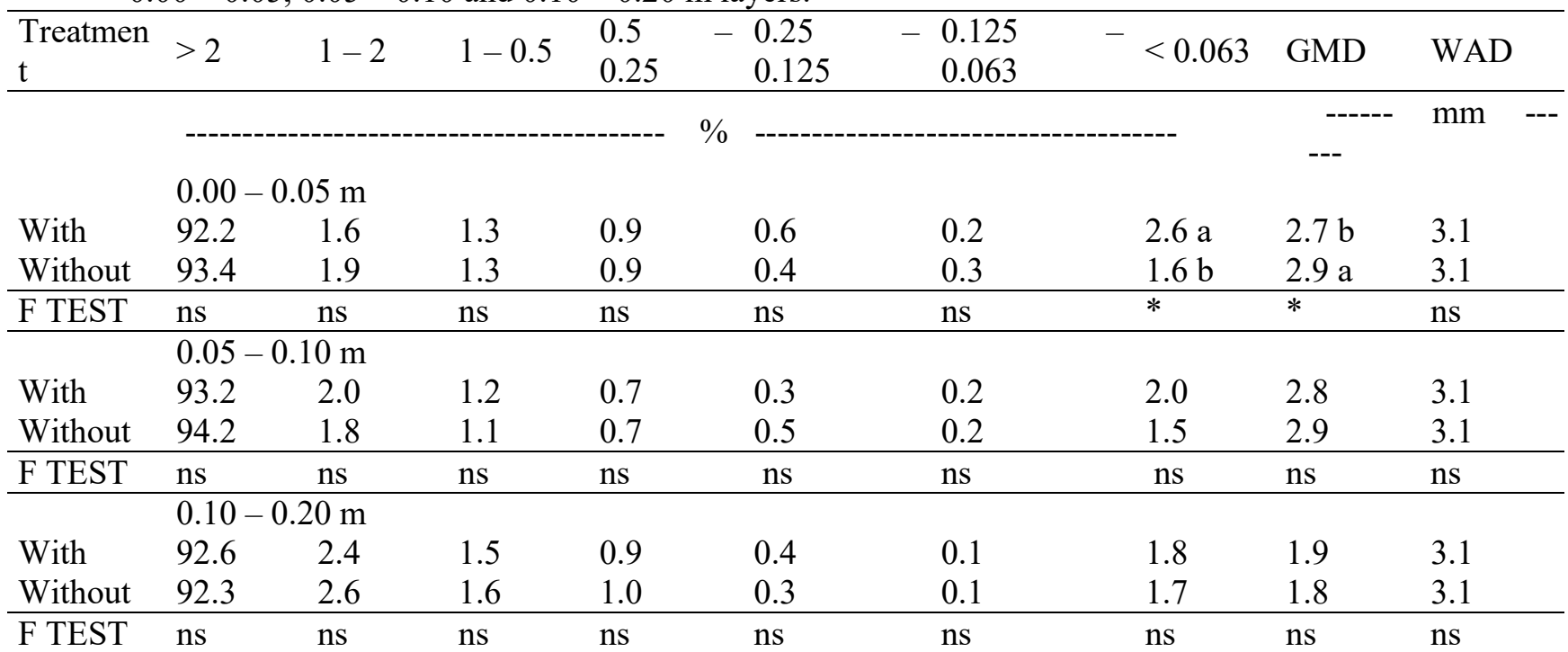

$\mathrm{GMD}=$ geometric mean diameter; WAD $=$ weighted average diameter; $* *$ significant at the $1 \%$ probability level $(\mathrm{p}<.01) ; *$ significant at the $5 \%$ probability level $(.01=<\mathrm{p}<.05)$; ns not significant $(\mathrm{p}>=.05)$. Means followed by the same lowercase letter in the column do not differ from one another by the Scott-Knott test at the $5 \%$ probability level.

It was observed that in the soil surface, the SMBF succession system presented a significantly larger amount of soil constituting large aggregates, in the class larger than $2 \mathrm{~mm}$, in relation to the other succession systems (Table 5). According to Basso and Reinert (1998), the values of larger aggregates tend to increase over time in systems with increased organic carbon, due to the use of cover crops under a no-tillage system (TORRES et al., 2015), resulting in a higher geometric and weighted aggregate diameter (PEREIRA et al., 2011). The higher the amount of plant material deposited in coverage, the higher will be the aggregation and lower the susceptibility to erosive processes caused by the impact of raindrops (FERREIRA; SCHWARZ; STRECK, 2000).

Table 5. Mean values of the class size of aggregates (GMD, WAD) due to crop succession systems in the 0.00 $-0.05,0.05-0.10$ and $0.10-0.20 \mathrm{~m}$ layers.

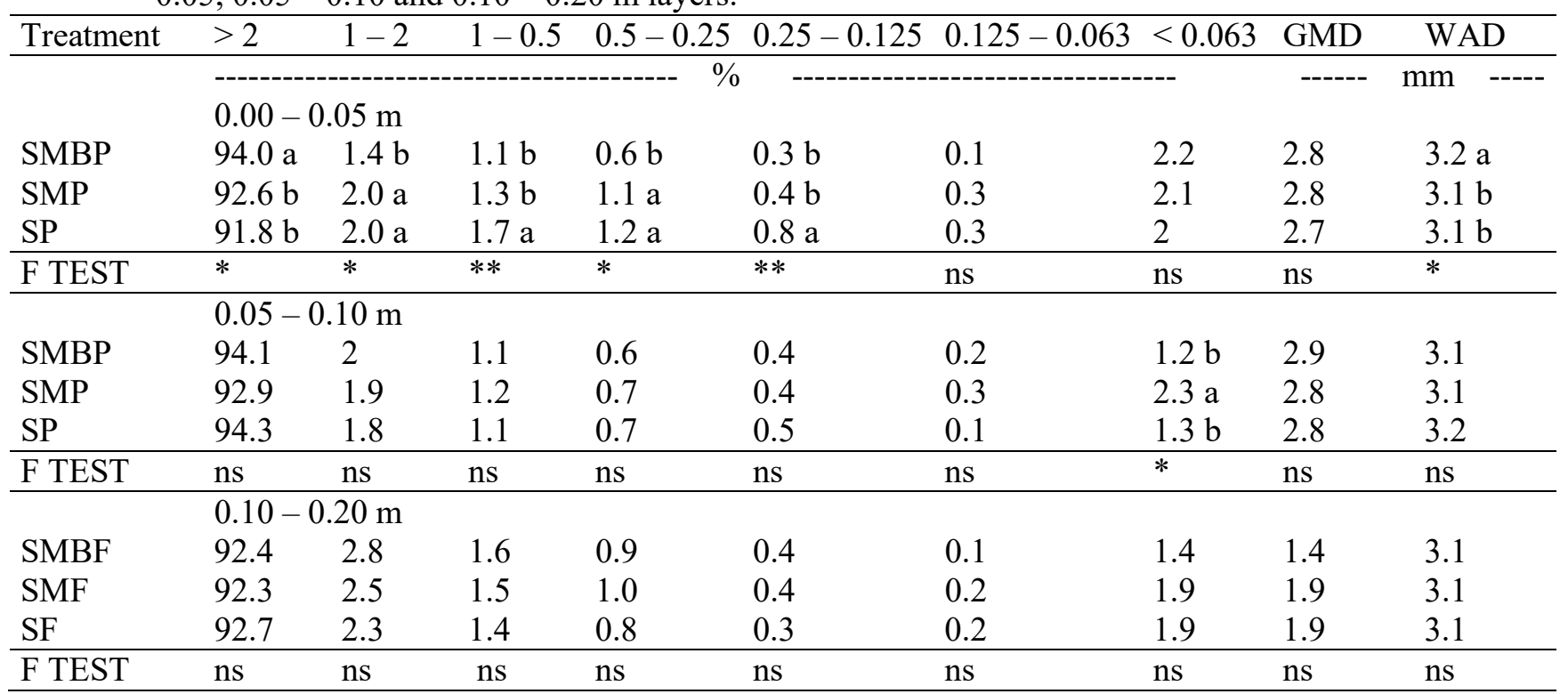

SMBF $=$ soybean/maize/brachiaria/fallow; SMF $=$ soybean/maize/fallow; SF $=$ soybean/fallow; GMD $=$ geometric mean diameter; $\mathrm{WAD}=$ weighted average diameter; $* *$ significant at the $1 \%$ probability level $(\mathrm{p}<.01)$; * significant at the $5 \%$ probability level $(.01=<\mathrm{p}<.05)$; ns not significant $(\mathrm{p}>=.05)$. Means followed by the same lowercase letter in the column do not differ from one another by the Scott-Knott test at the 5\% probability level. 
For the 2-1 and $0.5-0.25 \mathrm{~mm}$ classes, the reverse occurred. In that case, SMF and SF systems demonstrated the highest values, indicating that the soil mass of large aggregates, larger than $2 \mathrm{~mm}$, came from smaller classes (Table 5). These results are probably due to a greater distribution of roots in the superficial layer, contributing to a better soil structure, especially in the SMBF crops system with more waste input, where the root stocks of crops produce stable aggregates by supplying organic residues to decomposition, promoting high microbial proliferation in the rhizosphere (OADES, 1984). In addition, results indicate that the succession of crops involving maize, soybean and brachiaria made the formation and stabilization of larger diameter aggregates possible.

According to Santos et al. (2012), the contribution of organic material to the soil surface, through a no-tillage system, associated with the development of the root system of different cover crops, can contribute to the stability increase of larger diameter aggregates, improving the structural quality of the soil in the evaluated areas. Thus, it is assumed that this model of succession may have facilitated the activity of microorganisms, as well as a higher content of organic matter, factors that favor the larger diameter of the stable aggregates in water.

\section{CONCLUSIONS}

The treatment in which agricultural gypsum was applied presented better results in soil aggregation and higher levels of organic $\mathrm{C}$.

Soil scarification did not influence organic $\mathrm{C}$ contents and did not alter the stability of soil aggregates.

The system of succession of SMBF crops influenced the stability of aggregates in a positive way only in the soil surface. The same system presented a higher organic $\mathrm{C}$ content.

RESUMO: Estudos relativos ao monitoramento da qualidade do solo pelos atributos físicos são importantes para a avaliação e manutenção da sustentabilidade dos sistemas agrícolas, além de sinalizar o manejo adequado do ambiente, visando à sua conservação e produtividade. Este trabalho teve por objetivo avaliar a estabilidade de agregados e teor de carbono orgânico, após a aplicação de gesso, escarificação do solo e sucessão de culturas. Os tratamentos consistiram na ausência e adição de gesso agrícola, ausência e presença de escarificação do solo, e três sistemas de sucessão de culturas. O delineamento experimental foi em blocos casualizados, em esquema fatorial $2 \times 2 \times 3$ com oito repetições. Sendo avaliada a estabilidade dos agregados estáveis em água e teor de carbono orgânico do solo. O tratamento onde foi aplicado gesso agrícola e o sistema de sucessão SMBP apresentaram melhores resultados na agregação do solo e maiores teores de carbono orgânico.

PALAVRAS-CHAVE: Manejo do solo. Atributos físicos. Degradação do solo

\section{REFERENCES}

ALVARENGA, R. C.; FERNANDES, B.; SILVA, T. C. A.; RESENDE, M. Estabilidade de agregados de um Latossolo Roxo sob diferentes métodos de preparo do solo e de manejo da palhada do milho. Revista Brasileira de Ciência do Solo, Viçosa-MG, v.10, p.273-277, 1986.

ARF, O.; RODRIGUES, R. A. F.; NASCENTE, A. S.; LACERDA, M. C. Gesso aplicado na superfície do solo no desenvolvimento do arroz de terras altas sob plantio direto. Revista Brasileira de Engenharia Agrícola e Ambiental, v.18, n.11, p.1136-1141, 2014. https://doi.org/10.1590/1807-1929/agriambi.v18n11p1136-1141

ASSIS, R. L.; BAHIA, V. G. Práticas mecânicas e culturais de recuperação de características físicas dos solos degradados pelo cultivo. Informe Agropecuário, v.19, p.71-78, 1998.

BASSO, C. J.; REINERT, D. J. Variação da agregação induzida por plantas de cobertura de solo no inverno e plantio direto de milho em um solo Podzólico. Revista Ciência Rural, Santa Maria - RS, v. 28, n. 4, p. 567 571, 1998. https://doi.org/10.1590/S0103-84781998000400006 
The stability...

SANTOS, E. S. N. et al.

BONINI, C. S. B.; ALVES, M. C.; MONTANARI, R. Recuperação da estrutura de um Latossolo vermelho degradado utilizando lodo de esgoto. Revista Brasileira de Ciências Agrárias. Recife-PE, v.10, n.1, p.34-42, 2015. https://doi.org/10.5039/agraria.v10i1a4513

BRAIDA, J. A.; BAYER, C.; ALBUQUERQUE, J. A.; REICHERT, J. M. Matéria orgânica e seu efeito na física do solo. In: FILHO, O.K.et al. (Org.). Tópicos em ciência do solo. Sociedade Brasileira de Ciência do Solo, Viçosa-MG, v. 7, p.222-227, 2011.

BRIEDIS, C. et al. Soil organic matter pools and carbon-protection mechanisms in aggregate classes influenced by surface liming in a no-till system. Geoderma, Amsterdam, v. 170, p. 80-88, 2012.

https://doi.org/10.1016/j.geoderma.2011.10.011

CALONEGO, J. C.; ROSOLEM, C. A. Estabilidade de agregados do solo após manejo com rotações de culturas e escarificação. Revista Brasileira de Ciência do Solo, Viçosa-MG, v. 32, p. 1399-1407, 2008. https://doi.org/10.1590/S0100-06832008000400004

CARVALHO FILHO, A. et al. Métodos de preparo do solo: alterações na rugosidade do solo. Engenharia Agrícola, Jaboticabal-SP, v. 27, n. 1, p. 229-237, 2007. https://doi.org/10.1590/S0100-69162007000100017

CASTRO FILHO, C.; MUZILLI, O.; PODANOSCHI, A. L. Estabilidade dos agregados e sua relação com o teor de carbono orgânico num Latossolo Roxo distrófico, em função de sistemas de plantio, rotações de culturas e métodos de preparo das amostras. Revista Brasileira de Ciência do Solo, Viçosa-MG, v. 22, n. 3, p. 527538, 1998. https://doi.org/10.1590/S0100-06831998000300019

COSTA JÚNIOR, C. et al. Carbono em agregados do solo sob vegetação nativa, pastagem e sistemas agrícolas no bioma Cerrado. Revista Brasileira de Ciência do Solo, Viçosa-MG, v. 33, n. 4, p. 1-12, 2012.

https://doi.org/10.1590/S0100-06832012000400025

EMBRAPA - Manual de métodos de análise de solo. Empresa Brasileira de Pesquisa Agropecuária. Centro Nacional de Pesquisa de Solos, Rio de Janeiro-RJ, 230 p. 2011.

EMBRAPA. Sistema brasileiro de classificação dos solos. Empresa Brasileira de Pesquisa Agropecuária, 3. ed. Brasília-DF, 353 p. 2013.

FERREIRA, T. N.; SCHWARZ, R. A.; STRECK, E. V. Solos: manejo integrado e ecológico - elementos básicos, EMATER/RS, Porto Alegre - RS, p. 95, 2000.

FOIS, D. A. F.; LANA, M. C.; ALVAREZ, J. W. R.; FRANDOLOSO, J.; VERA, L. R. Q.; TIECHER, T. Resposta da soja ao gesso agrícola em plantio direto no Paraguai. Revista Ceres, v.65, n.5, p.450-462, 2018. https://doi.org/10.1590/0034-737x201865050010

GARCIA, R. A. \& ROSOLEM, C. A. Aggregates in a Rhodic Ferralsol under no-tillage and crop rotation, Pesquisa Agropecuária Brasileira, Brasília-DF, v.45, p.1489-1498, 2010. https://doi.org/10.1590/S0100204X2010001200021

HANKE, D.; DICK, D. P. Aggregate stability in soil with humic and histic horizons in a toposequence under Araucaria forest. Revista Brasileira de Ciência do Solo, Viçosa-MG, v. 41, 2017. https://doi.org/10.1590/18069657rbcs20160369

INAGAKI, T. M.; SÁ, J. C. M.; CAIRES, E. F.; GONÇALVES, D. R. P. Lime and gypsum application increases biological activity, carbon pools, and agronomic productivity in highly weathered soil. Agricultural Economics Research, Washington, v. 231, p. 156-165, 2016. https://doi.org/10.1016/j.agee.2016.06.034

KEMPER, W. D.; CHEPIL, W. S. Size distribution of aggregates. In: Methods of soil analysis - Physical and mineralogical properties, including statistics of measurement and sampling. Ed.s: BLACK, C. A., EVANS, D. 
The stability...

D., WHITE, J. L., ENSMINGER, L. E.; CLARK, F. E. Madison, American Society of Agronomy, p. 499-510. (Agronomy Series, 9), 1965.

LOSS, A.; PEREIRA, M. G.; SCHULTZ, N.; ANJOS, L. H. C.; SILVA, E. M. R. Atributos químicos e físicos de um Argissolo Vermelho-Amarelo em sistema integrado de produção agroecológica. Pesquisa Agropecuária Brasileira, Brasília-DF, v. 44, p. 68-75. 2009. https://doi.org/10.1590/S0100-204X2009000100010

MASCHIETTO, E. H. G. Gesso agrícola na produção de milho e soja em solo de alta fertilidade e baixa acidez em subsuperfície em plantio direto. 2009. 56 f. Dissertação (Mestrado em Agricultura) - Universidade Estadual de Ponta Grossa, Ponta Grossa, 2009.

MATAIX-SOLERA, J.; CERDÀ, A.; ARCENEGUI, V.; ZAVALA, L. M. Fire effects on soil aggregation: A review. Earth -Science Reviews, v. 109, n. 1-2, p. 44-60, 2011.

https://doi.org/10.1016/j.earscirev.2011.08.002

MATOS, E. S.; MENDONÇA, E. S.; LEITE, L. F. C.; GALVÃO, J. C. C. Estabilidade de agregados e distribuição de carbono e nutrientes em Argissolo sob adubação orgânica e mineral. Pesquisa Agropecuária Brasileira, Brasília-DF, v.43, n.9, p. 1221-1230, 2008. https://doi.org/10.1590/S0100-204X2008000900017

MAZURANA, M.; LEVIEN, R.; MÜLLER, J.; CONTE, O. Sistemas de preparo de solo: alterações na estrutura do solo e rendimento das culturas. Revista Brasileira de Ciência do Solo, v.35, n.4, p.1197-1206, 2011. https://doi.org/10.1590/S0100-06832011000400013

MOTA, J. C. A.; FREIRE, A. G.; ASSIS JÚNIOR, R. N. de. Qualidade Física de um Cambissolo sob sistemas de manejo. Revista Brasileira de Ciência do Solo, Viçosa-MG, v.37, p.1196-1206, 2013.

https://doi.org/10.1590/S0100-06832013000500009

NASCENTE, A. S.; LI, Y. C.; CRUSCIOL, C. A. C. Soil aggregation, organic carbon concentration, and soil bulk density as affected by cover crop species in a no-tillage system. Revista Brasileira de Ciência do Solo, Viçosa-MG, v. 39, p.871-879, 2015. https://doi.org/10.1590/01000683rbcs20140388

NEIS, L.; PAULINO, H. B.; SOUZA, E. D.; REIS, E. F.; PINTO, F. A. Gesso agrícola e rendimento de grãos de soja na região do sudoeste de Goiás. Revista Brasileira de Ciência Do Solo, Viçosa-MG, v.34, n.2, p.409416, 2010. https://doi.org/10.1590/S0100-06832010000200014

OADES, J. M. Soil organic matter and structural stability: mechanisms and implications for management. Plant Soil, 76, p. 319-337, 1984. https://doi.org/10.1007/978-94-009-6101-2_28

OLIVEIRA, V. S.; ROLIM, M. M.; VASCONCELOS, R. F. B.; PEDROSA, E. M. R. Distribuição de agregados e carbono orgânico em um Argissolo Amarelo distrocoeso em diferentes manejos. Revista Brasileira de Engenharia Agrícola e Ambiental, Campina Grande-PB, v.14, n.9, p.907-913, 2010. https://doi.org/10.1590/S1415-43662010000900001

PEREIRA, R. A. et al. Influência da cobertura de aveia preta e milheto sobre comunidade de plantas daninhas e produção de soja. Revista Brasileira de Ciências Agrárias, Recife-PE, v. 6, n. 1, p. 1-10, 2011. https://doi.org/10.5039/agraria.v6ila545

PORTELA, J. C.; COGO, N. P.; BAGATINI, T.; CHAGAS, J. P.; PORTZ, G. Restauração da estrutura do solo por sequências culturais implantadas em semeadura direta, e sua relação com a erosão hídrica em distintas condições físicas de superfície. Revista Brasileira de Ciência do Solo, Viçosa-MG, v.34, n.4, p.1353-1364, 2010. https://doi.org/10.1590/S0100-06832010000400032

RIBON, A. A.; CENTURION, J. F.; CENTURION, M. A. P. C.; FERNANDES, K. L.; HERMÓGENES, V. T. L. Alterações na estabilidade de agregados de Latossolo e Argissolo em função do manejo, na entrelinha da 
The stability...

seringueira (Hevea brasiliensis). Revista Árvore, Viçosa-MG, v.38, p.1065-1071, 2014.

https://doi.org/10.1590/S0100-67622014000600011

ROSA JUNIOR, E. J.; MARTINS, R. M. G.; ROSA, Y. B.M. G.; CREMON, C. Calcário e gesso como condicionantes físico e químico de um solo de Cerrado sob três sistemas de manejo. Pesquisa Agropecuária Tropical, Goiânia-GO, v. 36 (1), p. 37-44, 2006.

ROSSETTO, R.; VITTI, A. C.; GAVA, G. L. C; MELLIS, E. V.; VARGAS, V. P.; CANTARELLA, H.; PRADO, H.; DIAS, F. L. F.; LANDELL, M. G. A.; BRANCALIÃO, S. R.; GARCIA, J. C. Cana-de-açúcar Cultivo com sustentabilidade, n. 142. International plant nutrition institute, Piracicaba-SP, p. 13, 2013.

SALTON, J. C.; MIELNICZUK, J.; BAYER, C.; BOENI, M.; CONCEIÇÃO, P. C.; FABRÍCIO, A. C.; MACEDO, M. C. M.; BROCH, D. L. Agregação e estabilidade de agregados do solo em sistemas agropecuários em Mato Grosso do Sul. Revista Brasileira de Ciência do Solo, Viçosa-MG, v. 32, n. 1, p. 11 21, 2008. https://doi.org/10.1590/S0100-06832008000100002

SALTON, J. C.; TOMAZI. M. Sistema Radicular de Plantas e Qualidade do Solo. Comunicado Técnico 198. Embrapa Agropecuária Oeste, Dourados. 6 pp. 2014.

SANTOS, N. Z.; DIECKOW, J.; BAYER, C.; MOLIN, R.; FAVARETTO, N.; PAULETTI, V.; PIVA, J. T. Forages, cover crops and related shoot and root additions in no-till rotations to $\mathrm{C}$ sequestration in a subtropical Ferralsol. Soil \& Tillage Research, Amsterdam, v.111, n.2, p.208-218, 2011.

https://doi.org/10.1016/j.still.2010.10.006

SANTOS, G. G.; SILVEIRA, P. M.; MARCHÃO, R. L.; PETTER, F. A.; BECQUER, T. Atributos químicos e estabilidade de agregados sob diferentes culturas de cobertura em Latossolo do cerrado. Revista Brasileira de Engenharia Agrícola e Ambiental, Campina Grande-PB, v.16, n.11, p.1171-1178, 2012. https://doi.org/10.1590/S1415-43662012001100005

SHAVER, T. M.; PETERSON, G. A.; AHUJA, L. R.; WESTFALL, L. A.; DUNN, G. Surface Soil properties after twelve years of dryland no-till management. Soil Science Society of America, v. 66, p. 1296-1303, 2002. https://doi.org/10.2136/sssaj2002.1296

SILVA, É. A.; Oliveira, G. C.; Carducci, C. E.; Silva, B. M.; Serafim, M. E. Aggregates morphometry of a Inceptisol under conservationist system. Semina: Ciências Agrárias, Londrina-PR, v. 37, n. 3, p. 1165-1176, 2016. https://doi.org/10.5433/1679-0359.2016v37n3p1165

SPIGEL, H.; MENTLER, A. Effects on Aggregate Stability and P-contents under diferente tillage systems. Poster der Fachgruppe Bonden und Fachgruppe Dungemittel. ALVA Arbeitsgemeinschaft Landwirtschaftlicher versuchsantalten, Jahrestagung. P. 216-217, 2003.

TORMENA, C. A.; FIDALSKI, J.; ROSSI JUNIOR, W. Resistência tênsil e friabilidade de um Latossolo sob diferentes sistemas de uso. Revista Brasileira de Ciência do Solo, v. 32, n. 1, p. 33-42, 2008.

https://doi.org/10.1590/S0100-06832008000100004

TORRES, J. L. R.; PEREIRA, M. G.; ASSIS, R. L. de.; SOUZA, Z. M. de. Atributos físicos de um Latossolo vermelho cultivado com plantas de cobertura, em semeadura direta. Revista Brasileira de Ciência do Solo, Viçosa-MG, v. 39, n. 2, p. 428-437, 2015. https://doi.org/10.1590/01000683rbcs20140597

VEZZANI, F. M.; MIELNICZUK, J. Agregação e estoque de carbono em Argissolo submetido a diferentes práticas de manejo agrícola. Revista Brasileira de Ciência do Solo, Viçosa-MG, v.35, p.213-223, 2011. https://doi.org/10.1590/S0100-06832011000100020 
The stability...

SANTOS, E. S. N. et al.

YODER, R. E. A direct method of aggregate analysis of soil and a study of the physical nature of erosion losses. Journal of America Society of Agronomy, v.28, p.337-357, 1936.

https://doi.org/10.2134/agronj1936.00021962002800050001x

ZAMBROSI, F. C. B.; ALLEONI, L. R. F.; CAIRES, E. F. Nutrient concentration in soil water extracts and soybean nutrition in response to lime and gypsum applications to an acid Oxisol under no-till system. Nutrient Cycling in Agroecosystems, v.79, n.2, p.169-179, 2007. https://doi.org/10.1007/s10705-007-9105-7

ZANDONÁ, R. R.; BEUTLER, A. N.; BURG, G. M.; BARRETO, C. F.; SCHMIDT, M. R. Gesso e calcário aumentam a produtividade e amenizam o efeito do déficit hídrico em milho e soja. Pesquisa Agropecuária Tropical, v.45, n.2, p.128-137, 2015. https://doi.org/10.1590/1983-40632015v4530301 